\title{
Efficiency Analysis of Additions of Ice Flake in Cargo Hold Cooling System of Fishing Vessel
}

\author{
Amiadji $^{1}$, Edi Jadmiko², Yosef Novian Andy Prasetyo ${ }^{3}$
}

\begin{abstract}
Indonesia coast is as a fishermen. The process of preserving fish after being caught will determine how good the product quality. One of process on preserving fish that can be done is to perform the cooling process using a cooling machine on board. Refrigeration system certainly requires high electrical power consumption. That high power usage can be reduced as much as possible, one of which is to add chopped ice (ice flake) on a fishing boat cargo space, so that the load for cooling can be reduced.The purpose of this thesis is to find out how the influence of the addition of ice flake on cooling load in the cargo hold of fishing vessels, and to know how much power is used when the cooling machine is combined with the addition of ice flake. In this analysis cooling load calculation refers to the standard ISO 7547. From the results of analysis found that the addition of ice flake on cargo space can reduce cooling load and can reduce electricity consumption day in the main vessel for the addition comparison flake ice and fish weight of $1: 1$.
\end{abstract}

Keywords - fish cooling method, ice flake, refrigeration system

\section{. I $^{1}$ INTRODUCTION}

$\mathrm{T}_{1}$ he potential of Indonesia's natural resources are very abundant. With its vast area that $2 / 3$ is the region of the sea, and specifically to fisheries is expected to be a featured sector of the national economy. Sustainable potential Indonesian marine fish resources of 6.5 million tons per year spread in the territorial waters of Indonesia and the Indonesian Exclusive Economic Zone waters (ZEEI) divided into nine main area of Indonesian sea area.

Indonesia has the potential of catching fish to reach 130 million tons, equivalent to $\mathrm{Rp} 2,500$ trillion to $\mathrm{Rp}$ 3,000 trillion per year. However the problem is when compared with other countries more advanced maritime, Indonesia fishermen technology is still lacking.

The process of preserving fish after being caught will determine whether or not the product fish. One process of preserving fish that can be done one of which is to perform the cooling process in order to slow the growth of bacteria, which can lead to faster rotting fish. Therefore, the cooling process in the cargo hold of fishing vessels is one thing that is quite important, in order to maintain the freshness of the fish.

But the fish cooling process in the cargo hold by using a refrigeration system would require considerable power [9]. Great power usage can be reduced as much as possible, one of which is to add chopped ice (ice flake) on a cargo hold. So that the load for cooling can be reduced.

\footnotetext{
${ }^{1}$ Amiadji, Department of Marine Engineering, Institut Teknologi Sepuluh Nopember, Surabaya 60111, Indonesia, Email :amiadji@yahoo.com

Edi Jadmiko is with Department of Marine Engineering, Institut Technologi Sepuluh Nopember, Surabaya 60111, Indonesia. Email:gusjadmiko@gmail.com

Yosef Novian Andy Prasetyo, Department of Marine Engineering, Institut Teknologi Sepuluh Nopember, Surabaya 60111, Indonesia, Email: yosef.novian@gmail.com
}

Therefore, this study,is to analyzed the efficiency of the addition of chopped ice (flake ice) on the cargo hold cooling system of the fishing vessels. So that the future of this study are expected to provide information about how efficient the addition of ice flake in the cargo hold of the fishing vessel.

\section{LITERATURE REVIEW}

\section{A. Refrigeration System}

Refrigeration is the production or utilization and maintenance of the temperature levels of a substance or a room on the lower level of the ambient temperature or the surrounding atmosphere by means of the withdrawal or the heat absorption of the substance or the room.

Refrigeration can be referred to as a process of moving heat from one material or a room to a material or other room [1], while according to Hartanto (1985) cooling process or refrigeration is a process of heat absorption on an object where this process occurs due to the evaporation process materials cooler (refrigerant), and according to Arismunandar and Saito (2005) refrigeration is an attempt to maintain a low temperature, a process cools the air so as to achieve the temperature and humidity in accordance with the conditions required to air condition of a particular room, the temperature factor and temperature are very role in nurturing and maintaining the value of the freshness of the fish [2].

Refrigeration utilizing the properties of heat (thermal) of the refrigerant material while the material was changed circumstances of a liquid form into the form of gas or vapor and instead of gas back into a liquid [4].

In a mechanical refrigeration system, there was few simple physical processes. In the terms of thermodynamics, the whole process of change involved thermal power, which are grouped on the latent heat of evaporation, sensible heat, latent heat of condensation and others. According to Sofyan Ilyas (1993), a 
refrigeration cycle sequentially beginning of compression, through condensor (condensation), the setting expansion and ends on evaporator (evaporation).

A refrigeration cycle in one refrigeration system is as follows:

1. Compression.

Refrigerant superheat steam temperature and low pressure originating from evaporating process is compressed by the compressor into a high pressure and temperature steam that then easily condensed vapor back into a liquid in the condenser.

2. Condensation
Condensation process is the process of expulsion or removal of heat from the refrigerant vapor temperature and high pressure compressors to medium compression.

3. Expansion.

Expansion is the process of setting up an opportunity for the liquid refrigerant to expand in order to then be evaporated in the evaporator.

4. Evaporation.

in this process, the liquid refrigerant is in a metal pipe evaporator to boil and evaporate at a constant temperature, despite having to absorb large amounts of heat from the surrounding environment and the flow of substances in the form of food in an enclosed space insulated. The heat that is absorbed is called "latent heat of vaporization.

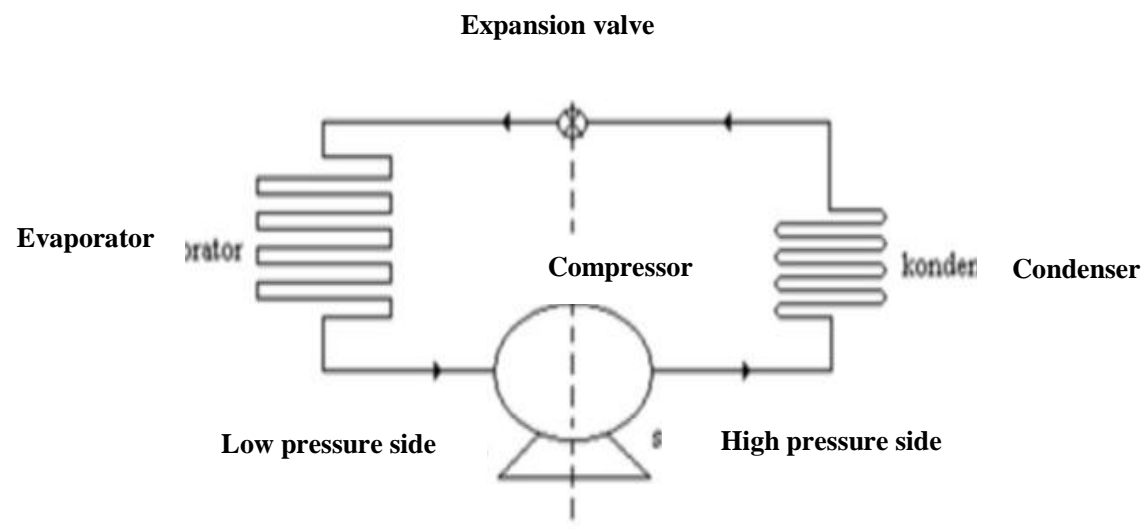

Figure. 1.Refrigeration system

\section{B.Ice Flake}

Ice (small ice or fragmentary ice) is the term given to a lot of ice made in the form of tiny pieces, which in the trade is known as ice-keeping (flake ice), ice chunks or ice slab (slice ice), ice tube (tube ice), ice cubes, ice plate (plate ice), ice ribbon (ribbon ice) and others [5]. Ice in bulk form is more effective (fast) in a cool rather than the form of ice cubes (ice block) because more surface area, so it is also faster liquid. In other words, the smaller the grain size of the ice faster and easier ability to cool it melts [6]).

Ice has a large enough cooling power. Each one kilogram of ice that melts at $0^{\circ} \mathrm{C}$ can absorb as much as $80 \mathrm{kcal}$ of heat to melt into water $0^{\circ} \mathrm{C}$ and has a melting point of ice on $0^{\circ} \mathrm{C}$.Proses cooling occurs when ice contact with fish $\left(20^{\circ} \mathrm{C}\right)$ transfers heat to the ice, and ice $\left(0^{\circ} \mathrm{C}\right)$ accept or the heat absorbing for use in liquefaction.

C. Cooling capacity

Of the two laws of thermodynamics which states the amount of energy or heat to move from one room to another room is for a reduction in the space. In ISO7547 cooling capacity can be calculated by the equation:

$\mathrm{Q}_{\text {Total }}=\mathrm{Q}_{\text {Product }}+\mathrm{Q}_{\text {Transmision }}+\mathrm{Q}_{\text {Solar Radiation }}+\mathrm{Q}_{\text {Additional }}$ (1) where:

$\mathrm{Q}_{\text {Total }}=$ Total cooling capacity $(\mathrm{W})$

$\mathrm{Q}_{\text {Product }}=$ Heat gain from product/fish $(\mathrm{W})$

$\mathrm{Q}_{\text {Tran }}=$ Heat loss due to the difference in temperature inside and outside the refrigerator (W)
$\mathrm{Q}_{\text {Solar }}=$ Heat loss due to exposure to the sun's heat into the cool room walls (W)

$\mathrm{Q}_{\text {AdditionaL }}=$ Additional heat loss derived from human activities, equipment, etc. (W)

$\mathrm{Q}=\mathrm{m} \cdot \mathrm{c} \cdot \Delta \mathrm{T}$

where:

Q $\quad=$ Heat $($ Kcal $)$

$\mathrm{m} \quad=$ Mass $(\mathrm{kg})$

c $\quad=$ Heat specific $\left(\mathrm{kkal} / \mathrm{kg}{ }^{\circ} \mathrm{C}\right)$

$\Delta \mathrm{T} \quad=$ Temperature different $\left({ }^{\circ} \mathrm{C}\right)$

$\mathrm{q}=\mathrm{U} \cdot \mathrm{A} \cdot(\mathrm{to}-\mathrm{ti})$

where :

$q \quad=$ Total Heat $(\mathrm{W})$

$U \quad=$ Heat transfer coefficient $\left(\mathrm{W} / \mathrm{m}^{2 \mathrm{o}} \mathrm{C}\right)$

$A=$ Area $\left(\mathrm{m}^{2}\right)$

(to-ti) $=$ Temperature difference $\left({ }^{\circ} \mathrm{C}\right)$

$\Phi_{\mathrm{S}}=\sum \mathrm{A}_{\mathrm{v}} \mathrm{K} \Delta \mathrm{T}$

where :

$\Phi_{\mathrm{S}} \quad=$ Total heat gain $(\mathrm{w})$

$\mathrm{A}_{\mathrm{v}} \quad=$ Area exposed to solar radiation $\left(\mathrm{m}^{2}\right)$

$\mathrm{K}=$ Heat transfer coefficient

$\Delta \mathrm{T} \quad=$ Temperature difference $\left({ }^{0} \mathrm{C}\right)$

\section{METHOD}

This analysis is divided into several stages. The first stage is to determine the primary measure of the 
fishing vessel, while the vessel is in the analysis in this study is the fishing vessel 80GT size.

Having obtained the ship general arrangement,then do layout design and space measurements of the fishing vessel cargo hold. Furthermore, after the data and the layout of the fishing vessel obtained, The cooling capacity of the cargo hold can be calculated.

In the calculation, then do cooling capacity calculation in cargo hold without added ice flake, and with added.For the calculation of cooling capacity with the addition of flake ice in the cargo hold, done three variations of weight gain ice flake. As many as 1: $3,1: 2$ and 1: 1 as compared to the weight of fish in each cargo hold.

Having obtained the cooling capacity in every cargo hold, made the determination that the cooling machine will be installed in each room hatch in accordance with the cooling capacity in each cargo hold. So from there it can be known how much electric power required by the engine coolant in each cargo hold.

Having obtained the refrigeration capacity installed in each room hatch at each variation of the addition of ice flake, analyzed the effect of adding flake ice at each variation, and analysis of power consumption when the cooling machine combined with flake ice machine.

\section{RESULT AND DISCUSSION}

\section{A. Ship General Arrangement}

In the analysis of the efficiency of this cooling load, the vessel used is the fishing vessel 80 GT design with room temperature fish hold $-20^{\circ} \mathrm{C}$ or $253^{\circ} \mathrm{K}$. Data rig as follows:

\section{Principal dimension:}

Length overall (Loa) $=20.57 \mathrm{~m}$

Length of waterline(Lwl) $=19.18 \mathrm{~m}$

Length between perpendiculars (Lpp)

$=17.94 \mathrm{~m}$

Breadth moulded $(\mathrm{B})$

$=6.20 \mathrm{~m}$

Draught Design (T)

$=2.75 \mathrm{~m}$

Service speed $(\mathrm{Vs})$

$=9.5 \mathrm{knot}$

Endurance

$=30$ days

GT

$=80$ tons

Fish Hold

$=70 \mathrm{~m}^{3}$

From the ship general arrangement, there are 6 cargo hold that used to store the fish. The dimensions of the cargo hold are as follows:

\section{B. Cooling Load Calculation Without Ice Flake}

In the calculation of cooling load without ice flake by ISO-7547, From these calculations the results obtained ineach cargo hold as follows:

TABLE 1.

CARGO HOLD DIMENSION

\begin{tabular}{lccc}
\hline \multirow{2}{*}{ Dimension } & \multicolumn{3}{c}{ Cargo hold } \\
\cline { 2 - 4 } & 1 PS, 1 SB & 2 PS, 2 SB & 3 PS, 3 SB \\
\hline B1 (m) & 1.98 & 2.28 & 2.28 \\
B2 (m) & 1.18 & 2.02 & 2.28 \\
H (m) & 2 & 2 & 2 \\
L (m) & 2.8 & 2.8 & 2.8 \\
\hline
\end{tabular}

TABLE 2.

\begin{tabular}{cc} 
Total Cooling Load Without ICE FlaKe \\
\hline Cargo hold & Cooling Load $(\mathrm{kW})$ \\
\hline 1 PS & 6.95 \\
1 SB & 6.95 \\
2 PS & 8.98 \\
2 SB & 8.97 \\
3 PS & 9.42 \\
3 SB & 9.42 \\
\hline
\end{tabular}

Total load (kW) 50.68

TABLE 3.

ELECTRICAL POWER LOAD WITHOUT ICE FLAKE

\begin{tabular}{|c|c|c|c|c|c|c|}
\hline Cargo hold & Series & Compressor type & Cooling capacity $(\mathrm{kW})$ & Compressor power $(\mathrm{kW})$ & $\begin{array}{c}\text { Fan power condensor } \\
(\mathrm{kW})\end{array}$ & $\begin{array}{c}\text { Fan power evaporator } \\
(\mathrm{kW})\end{array}$ \\
\hline $1 \mathrm{PS}$ & $05 \mathrm{~L}$ & 4DC5.2 & 7.26 & 4.67 & 0.36 & 0.5 \\
\hline $1 \mathrm{SB}$ & $05 \mathrm{~L}$ & 4DC5.2 & 7.26 & 4.67 & 0.36 & 0.5 \\
\hline $2 \mathrm{PS}$ & $08 \mathrm{~L}$ & 4TCS8.2 & 8.97 & 6.09 & 0.5 & 0.5 \\
\hline $2 \mathrm{SB}$ & $08 \mathrm{~L}$ & 4TCS8.2 & 8.97 & 6.09 & 0.5 & 0.5 \\
\hline $3 \mathrm{PS}$ & $08 \mathrm{~L}$ & 4TCS8.2 & 10.06 & 6.42 & 0.5 & 0.5 \\
\hline \multirow[t]{2}{*}{$3 \mathrm{SB}$} & $08 \mathrm{~L}$ & 4TCS8.2 & 10.06 & 6.42 & 0.5 & 0.5 \\
\hline & & Total & 52.58 & 34.36 & 2.72 & 3 \\
\hline
\end{tabular}

Total power

$40.08 \quad \mathrm{~kW}$


International Journal of Marine Engineering Innovation and Research, Vol. 1(3), Jun. 2017. 196-203 (pISSN: 2541-5972, eISSN:2548-1479)

\section{Cooling Load Calculation With Ice Flake}

room fit 1: 1, 1: 2 and 1: 3.Ice flake has the ability to

In the cooling load calculation with added ice flake, to absorb the heat produced big fish $80 \mathrm{kkal} / \mathrm{kg}$. vary the addition of ice flake by weight of fish in each

TABLE 4.

PRODUCT LOAD WITH ICE FLAKE 1:3

\begin{tabular}{cccc}
\hline $\begin{array}{c}\text { Cargo } \\
\text { hold }\end{array}$ & $\begin{array}{c}\text { Q fish } \\
(\mathrm{kW})\end{array}$ & $\begin{array}{c}\text { Q ice flake } \\
(\mathrm{kW})\end{array}$ & $\begin{array}{c}\text { Q fish - Q } \\
\text { ice }(\mathrm{kW})\end{array}$ \\
\hline 1 PS & 4.95 & 0.3395755 & 4.62 \\
$1 \mathrm{SB}$ & 4.95 & 0.3395755 & 4.62 \\
2 PS & 6.74 & 0.4620806 & 6.28 \\
2 SB & 6.74 & 0.4620806 & 6.28 \\
3 PS & 7.18 & 0.4620806 & 6.69 \\
$3 \mathrm{SB}$ & 7.18 & 0.4620806 & 6.69 \\
\hline & & Total & 35.17
\end{tabular}

TABLE 5 .

PRODUCT LOAD WITH ICE FLAKE 1:2

\begin{tabular}{cccc}
\hline $\begin{array}{c}\text { Cargo } \\
\text { hold }\end{array}$ & $\begin{array}{c}\text { Q fish } \\
(\mathrm{kW})\end{array}$ & $\begin{array}{c}\text { Q ice flake } \\
(\mathrm{kW})\end{array}$ & $\begin{array}{c}\text { Q fish - Q } \\
\text { ice }(\mathrm{kW})\end{array}$ \\
\hline 1 PS & 4.95 & 0.514508 & 4.44 \\
1 SB & 4.95 & 0.514508 & 4.44 \\
2 PS & 6.74 & 0.700122 & 6.04 \\
2 SB & 6.74 & 0.700122 & 6.04 \\
3 PS & 7.18 & 0.745711 & 6.44 \\
3 SB & 7.18 & 0.745711 & 6.44 \\
\hline & & Total & 33.84
\end{tabular}

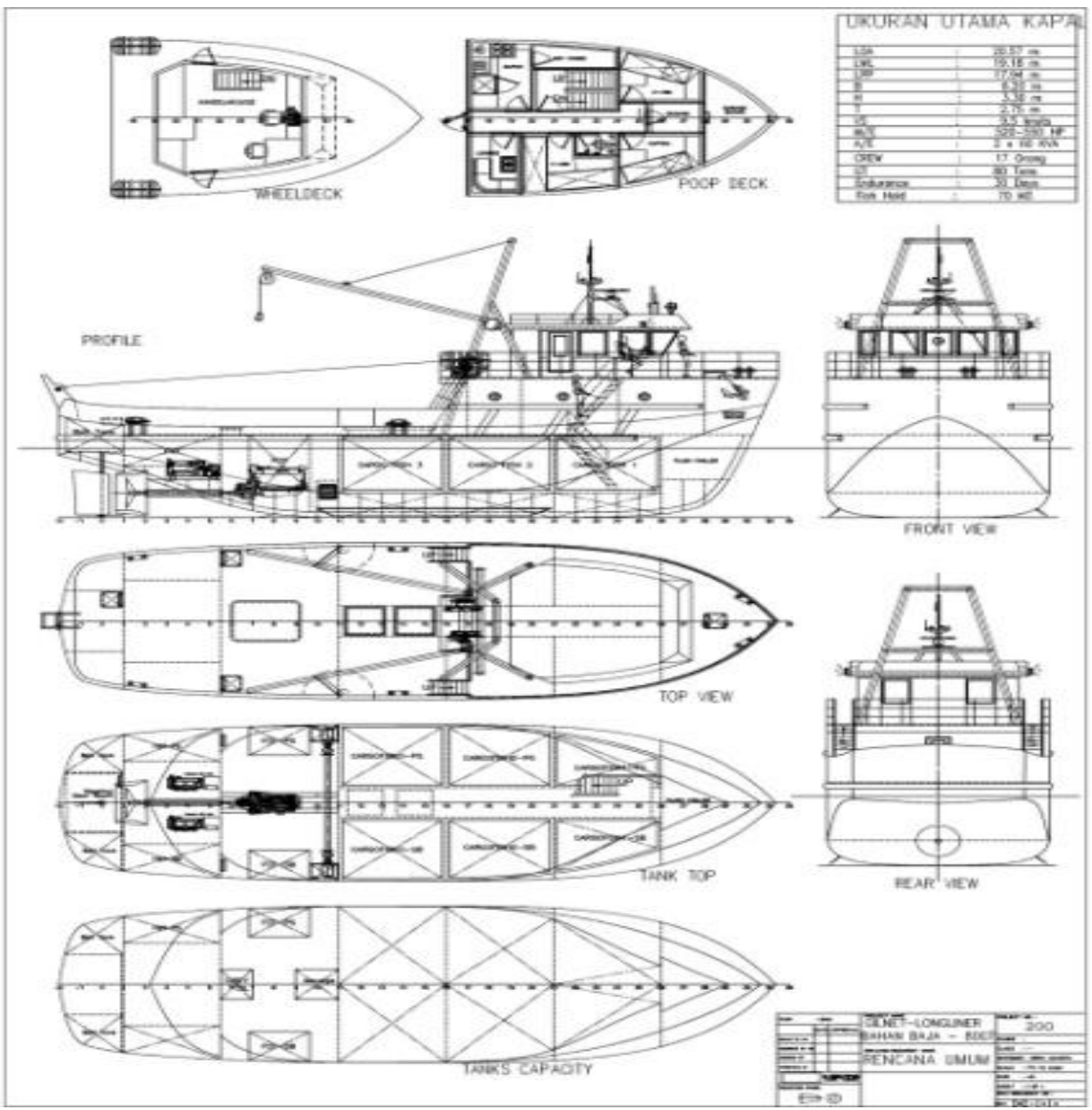

Figure. 2. General arrangement 
TABLE 6.

PRODUCT LOAD WiTH ICE FLAKE 1:1

\begin{tabular}{cccc}
\hline $\begin{array}{c}\text { Cargo } \\
\text { hold }\end{array}$ & $\begin{array}{c}\text { Q fish } \\
(\mathrm{kW})\end{array}$ & $\begin{array}{c}\text { Q ice flake } \\
(\mathrm{kW})\end{array}$ & $\begin{array}{c}\text { Q fish - Q } \\
\text { ice }(\mathrm{kW})\end{array}$ \\
\hline 1 PS & 4.95 & 1.0290167 & 3.93 \\
$1 \mathrm{SB}$ & 4.95 & 1.0290167 & 3.93 \\
$2 \mathrm{PS}$ & 6.74 & 1.4002442 & 5.34 \\
$2 \mathrm{SB}$ & 6.74 & 1.4002442 & 5.34 \\
$3 \mathrm{PS}$ & 7.18 & 1.4914229 & 5.69 \\
$3 \mathrm{SB}$ & 7.18 & 1.4914229 & 5.69 \\
\hline & & Total & 29.92
\end{tabular}

Having obtained the cooling load from fish in each

flake, then the total cooling load in the cargo hold is: cargo hold at each variation of the addition of ice

TABLE 7.

\begin{tabular}{cccc} 
TOTAL COOLING LOAD AT EACH VARIATION OF ICE FLAKE ADDIT \\
\cline { 2 - 4 } $\begin{array}{c}\text { Cargo } \\
\text { hold }\end{array}$ & \multicolumn{4}{c}{ Cooling load for Ice Flake variation } \\
\cline { 2 - 4 } 1 PS & 5.62 & 6.13 & $1: 3$ \\
1 SB & 5.62 & 6.13 & 6.31 \\
2 PS & 7.07 & 8.17 & 8.21 \\
2 SB & 7.07 & 8.17 & 8.21 \\
3 PS & 7.69 & 8.43 & 8.68 \\
$3 \mathrm{SB}$ & 7.69 & 8.43 & 8.68 \\
\hline Total & 40.76 & 45.48 & 46.41
\end{tabular}

After known the cooling capacity at each variation

expressed in the following table : of ice flake addition, the power consumption is

TABLE 8.

POWER CONSUMPTION AT EACH VARIATION OF ICE FLAKE ADDITION

\begin{tabular}{cccc}
\multicolumn{4}{c}{ Power Consumption kW/day } \\
\hline without & Ice flake & Ice flake & Ice flake \\
ice flake & $1: 3$ & $1: 2$ & $1: 1$ \\
\hline 961.92 & 948 & 906.24 & 831.36 \\
\hline
\end{tabular}

For adding variations of ice flake, required amount

power required is as follows: of ice flake according to the weight ratio of flake ice and the weight of the fish. So for flake ice machine

TABLE 9.

ICE FlaKe Machine POWER CONSUMPTION PER PRODUCTION

\begin{tabular}{cccccc}
\hline Ice flake variation & $\begin{array}{c}\text { Weight of ice } \\
(\mathrm{kg})\end{array}$ & Power $(\mathrm{kW})$ & Capacity $(\mathrm{kg} / \mathrm{h})$ & $\begin{array}{c}\text { Production } \\
\text { time }(\mathrm{h})\end{array}$ & $\begin{array}{c}\text { Total power consumed } \\
(\mathrm{kWh})\end{array}$ \\
\hline $1: 3$ & 1668.7 & 4.4 & 208.33 & 8.01 & 35.2444372 \\
$1: 2$ & 252.4 & 4.4 & 208.33 & 12.14 & 53.4006624 \\
$1: 1$ & 5056.8 & 4.4 & 208.33 & 24.27 & 106.801325 \\
\hline
\end{tabular}

To find out how much total power consumption required in each use of refrigeration combined with flake ice machine, it can be shown in the following table: 
TABLE 10.

TOTAL POWER CONSUMPTION ICE FLAKE MACHINE + COOLING MACHINE

\begin{tabular}{cccc}
\hline $\begin{array}{c}\text { Ice flake } \\
\text { variation }\end{array}$ & $\begin{array}{c}\text { Cooling } \\
\text { machine } \\
\text { (kW/day) }\end{array}$ & $\begin{array}{c}\text { ice flake } \\
\text { machine } \\
\text { (kW/day) }\end{array}$ & $\begin{array}{c}\text { Total } \\
\text { power } \\
(\mathrm{kW} / \text { day })\end{array}$ \\
\hline 0 & 961.92 & 0 & 961.2 \\
$1: 3$ & 948 & 35.2444372 & 983.24 \\
$1: 2$ & 906.24 & 53.4006624 & 959.64 \\
$1: 1$ & 831.36 & 106.801325 & 938.16 \\
\hline
\end{tabular}

\section{Data Analysis}

hold cooling load, and the power consumption on

Based on the calculations have been done, do an board. analysis of how the effect of flake ice to the cargo

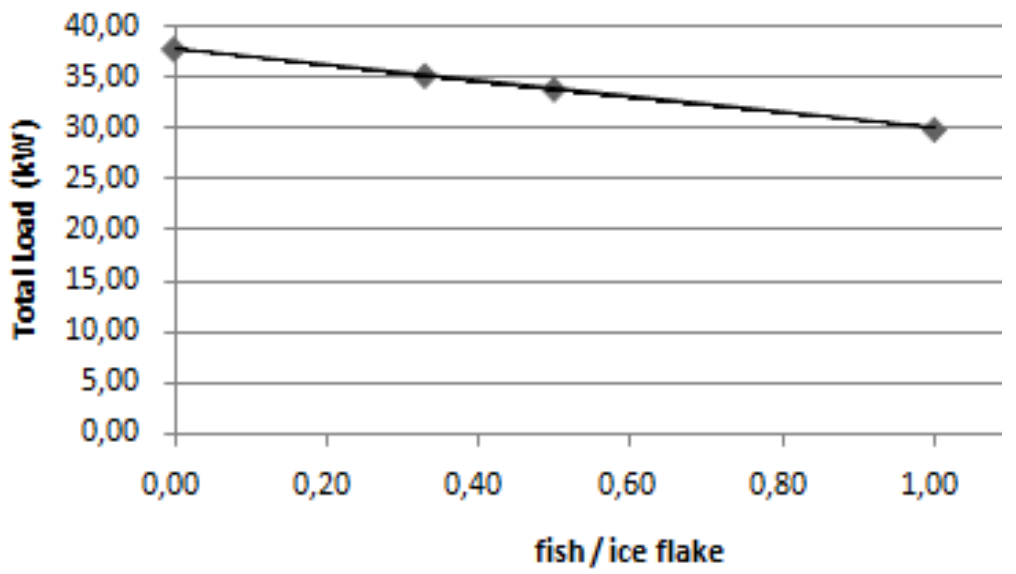

Figure.3. Cooling Load at Each Variation of Ice Flake Addition

In Figure 3 can be seen that for adding ice flake greater the ratio, the load generated from products decreased. And the greatest decrease in the cooling load is adding ice flake tovariation 1: 1 .

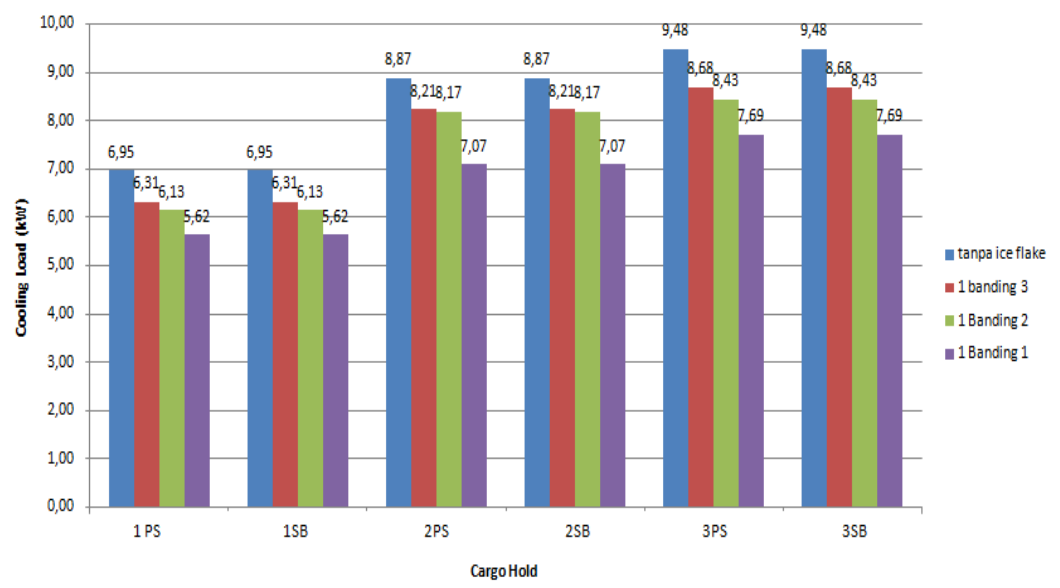

Figure.4. Cargo Hold Cooling Load

In Figure 4 we can see that for the cooling load in hold space also decreased to variations in weight gain ice flakethat more and more. 


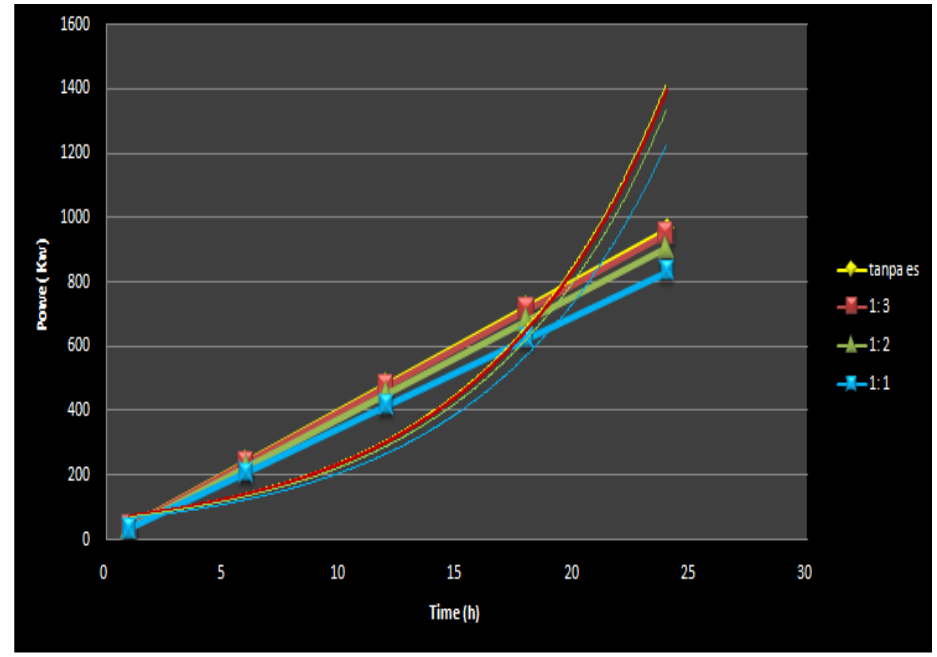

Figure. 5. Power Consumption of Cooling Machine

In the figure 5 can be seen that most small electric power usage experienced by adding ice flake variation 1: 1 , but that only power the electrical power used without the added of ice flake machine power . So that ice machines power consumption per production time should be added.

\section{Total Power Consumption PerDay}

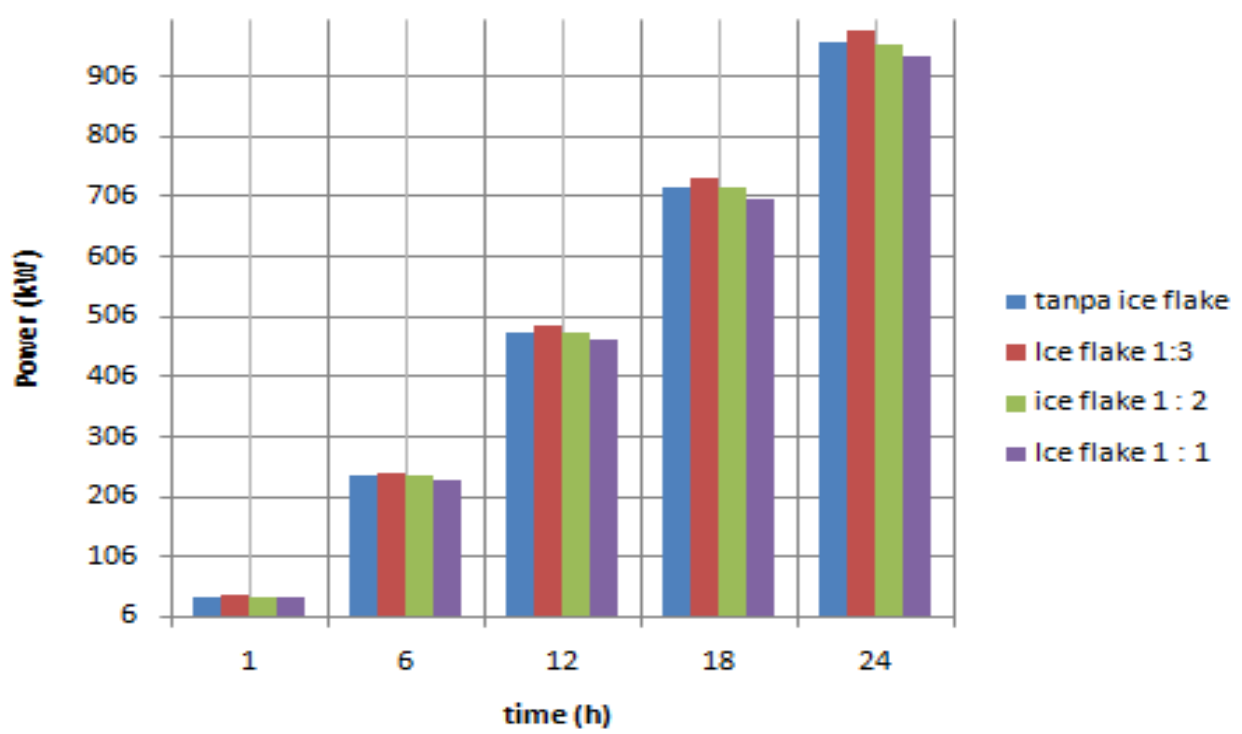

Figure.6.Cooling Machine Power + Ice Flake Machine Power

Figure 7 can be known to the total electric power consumption, the least experienced by ice flake with a ratio of 1: 1, being the largest variation experienced by adding ice flake $1: 3$

TABLE 11. ELECTRICAL POWER COST ESTIMATION

\begin{tabular}{ccccc}
\hline $\begin{array}{c}\text { Ice flake } \\
\text { variation }\end{array}$ & $\begin{array}{c}\text { total power } \\
(\mathrm{kWh})\end{array}$ & $\begin{array}{c}\text { price } \\
(\mathrm{Rp} / \mathrm{kVARh})\end{array}$ & $\begin{array}{c}\text { Cost per } \\
\text { hour }(\mathrm{Rp})\end{array}$ & $\begin{array}{c}\text { Cost per day } \\
(\mathrm{Rp})\end{array}$ \\
\hline 0 & 40.08 & 1114.74 & $52,563.27$ & $1,261,518.47$ \\
$1: 3$ & 40.97 & 1114.74 & $53,728.52$ & $1,289,484.59$ \\
$1: 2$ & 39.99 & 1114.74 & $52,438.72$ & $1,258.529 .21$ \\
$1: 1$ & 39.09 & 1114.74 & $51,265.00$ & $1,230,359.95$ \\
\hline
\end{tabular}

there it can be known variations of adding ice flake

From the tables can also be seen the estimated costs most efficient is the ratio $1: 1$. of electric power consumption per unit time. From 


\section{CONCLUSION}

From the results of calculations and data analysis has been done it can be concluded as follows :

1. The addition of flake ice in cargo hold of fishing vessels were able to reduce the cooling load that happens in a fishing vessel hold.

2. The electrical energy consumption of the cooling machine when combined with adding ice flake 1: $3,1: 2$ and 1: 1 is $984 \mathrm{~kW} /$ day; 906.24 / day; and $831 \mathrm{~kW} /$ day

From the calculation and analysis of technical data, adding ice flake on cargo space is able to reduce the capacity of the cooling load in the cargo hold of fishing vessels. Total weight of ice flake that efficient to be added than weight of fish is as much as 1: 1 . Besides that, adding flake ice can be reduce the cost of electrical energy consumption. However, when compared to the weight of fish that is capable transported in the cargo hold, the addition of ice flake is less efficient. Because of the added weight of flake ice the weight of flake that can be loaded is reduced. So that the results obtained from the sale of fish becomes less.

\section{REFERENCES}

[1] Alwi Asy'ari Aziz. 2012.’Desain Sistem Pendingin Ruang Muat Kapal Ikan Tradisional Dengan Memanfaatkan Uap Es Kering”. Jurnal teknik POMITS, Teknik Sistem Perkapalan FTK-ITS.

[2] Ardianto Rizki, Ir.Alam Baheramsyah M.Sc, dan Beni Cahyono ST.MT. 2012. "Desain Sistem Pendingin Ruang Muat kapal Ikan Tradisional Menggunakan Es kering Dengan Penambahan Eutectic Gel" Jurnal teknik POMITS, Teknik Sistem Perkapalan FTK-ITS.

[3] International Organization for Standarization 7547.2002."Ships and marine technology- Air conditioning and ventilation of accommodation spaces - Design conditions and basis of calculations"

[4] Jauhari Lutfi , 2012 , Dasar- Dasar Refrigerasi

[5] <http://lukmanhakimsmkn29.blogspot.co.id/2014/08/sistemkelistrikan-refrigerasi.html>

[6] Sovanda Bravo Yovan, Alam Baheramsyah, dan Taufik Fajar Nugroho. "Studi Perencanaan Jacketed Storage System Memanfaatkan CO2 Cair Sebagai Refrigeran', Jurnal teknik POMITS, Teknik Sistem Perkapalan FTK-ITS.

[7] Sulastri Suhana . 2011 . Pendinginan Ikan Dengan Es .Departemen Teknologi Hasil Perairan Fakultas Perikanan Dan Ilmu Kelautan Institut Pertanian Bogor,

[8] <http://suhanasulastri.blogspot.co.id/201/03/pendinginanikan-dengan-es.html>

[9] S. P. Fitri, M. B. Zaman, D. Priyanta, and M. Hidayat, "Application Waste Sawdust as Mixed Polyurethane Insulation in Traditional Cold Storage of Fishing Vessel," Int. J. Mar. Eng. Innov. Res., vol. 1, no. 2, Mar. 2017. 